tissue damage, this reaction has also been described in patients with CF. (4) The type IV delayed hypersensitivity reaction described in this paper is mediated by allergised cells.

In our patients but not in our controls there was a positive correlation between the MIs induced by $(a)$ lung and pancreatic tissue antigen $(\mathrm{r}=0.76),(b)$ lung and $A$ fumigatus $(\mathrm{r}=0.88)$, (c) lung and Pseudomonas $(\mathrm{r}==0.50)$ and $(d)$ Ps aeruginosa and $A$ fumigatus $(\mathrm{r}=0.86)$. The correlation coefficients between the MI induced by pancreatic tissue antigen and those induced by the other antigens were lower. The significance of these observations is not clear but there may be some common antigenic determinants giving rise to cross reactivity between lung and pancreatic tissue and between lung and $A$ fumigatus and $P s$ aeruginosa.

Most patients with CF who showed a greatly reduced MI to one antigen also showed a similarly reduced MI to the other antigens and although there were only a few patients in this study these results suggest that those patients who had the most severe condition also had the greatest reduction of their MI. In those patients with CF who responded well to prednisolone treatment their initially depressed MI returned to normal, which suggests that impaired cell-mediated immunity plays a part in the pathogenesis of CF. It seems, therefore, that investigation of the leucocyte MI to different antigens is of some benefit in the management of patients with $C F$.
We thank the Cystic Fibrosis Research Trust and the North-western Regional Health Authority for their support for this work.

Requests for reprints should be addressed to $\mathrm{Dr} \mathrm{H}$ McFarlane.

\section{References}

${ }^{1}$ Murray, M J, and Thal, A P, Annals of Internal Medicine, 1960, 53, 548.

2 Stein, A A, et al, fournal of Pediatrics, 1964, 65, 495.

${ }^{3}$ Mearns, M, Young, W, and Batten, J C, Thorax, 1965, 20, 385.

${ }^{4}$ Mearns, M, Longbottom, J L, and Batten, J C, Lancet, 1967, 1, 538.

${ }^{5}$ Warren, C P W, et al, Clinical Allergy, 1975, 1, 1.

${ }^{6}$ McFarlane, H, et al, British Medical fournal, 1975, 1, 423.

${ }^{7}$ S $\phi$ borg, M, and Bendixen, G, Acta Medica Scandinavica, 1967, 181, 247.

${ }^{8}$ Morley, J, Wolstencroft, R A, and Dumonde, D C, in Handbook of Experimental Immunology, ed D M Weir, vol 2, chap 28, p 20. Oxford, Blackwell, 1973.

${ }^{9}$ Pepys, J, et al, Proceedings of the 6th International Congress Allergology, ed B Rose, et al, p 221. Amsterdam, Excerpta Medica, 1968.

10 Wallwork, J C, et al, Clinical and Experimental Immunology, 1974, 18, 303.

${ }^{11}$ Cracco, G, et al, 5th Annual Meeting of the European Working Group for Cystic Fibrosis, Verona, Italy, 22-23 April 1974.

${ }^{12}$ Gell, P G H, and Coombs, R R A, (editors), Clinical Aspects of Immunology, 2 edn, p 588. Oxford, Blackwell, 1967.

${ }^{13}$ McFarlane, H, et al, Cystic Fibrosis News, 1975, 10(2), 6.

\title{
Role of doxapram in reducing pulmonary complications after major surgery
}

\author{
T H GAWLEY， J W DUNDEE， P K GUPTA， C J JONES
}

British Medical fournal, 1976, 1, 122-124

\begin{abstract}
Summary
In a double-blind study patients given a single dose of doxapram $1.5-2.0 \mathrm{mg} / \mathrm{kg}$ combined with morphine postoperatively had a significantly lower incidence of reflex postoperative cough and expectoracion of purulent sputum than patients given morphine alone. They also had significantly higher arterial oxygen tensions five days postoperatively. Smaller differences were found with naloxone combined with morphine.
\end{abstract}

\section{Introduction}

Despite advances in anaesthesia respiratory complications and some degree of hypoxia may still occur after upper abdominal operations. Many attempts have been made to solve this problem, and the various approaches used indicate basic lack of understanding of the factors involved.

In a study of the clinical and pharmacological effects of morphine combined with either the respiratory stimulant doxapram or the opiate antagonist naloxone Gupta and Dundee ${ }^{12}$

Queen's University Hospital and Royal Victoria Hospital, Belfast

T H GAWLEY, MD, FFARCS, consultant anaesthetist (present address: Belfast City Hospital)

$J$ W DUNDEE, MRCP, FFARCS, professor of anaesthetics

P K GUPTA, MD, DA, associate professor (present address: Banaras Hindu University, Varanasi-5, India)

C J JONES, BPHARM, MPS, clinical research associate (present address: A H Robins Company, Horsham, Sussex) noted a lowered incidence of postoperative pulmonary complications in those patients given doxapram. In that study respiratory complications were taken as the occurrence of coughing or the expectoration of purulent sputum or both during the first postoperative week. This surprising finding was considered to be of such clinical significance that a more detailed study using more objective methods of assessment of respiratory complications was undertaken in the same centre. We report here the findings in a further 95 patients recovering from upper abdominal operations and analyse the pooled data for both series, which totalled 235 patients.

Patients included in the study were those having routine postoperative analgesia with intravenous morphine alone or combined with a respiratory stimulant dose of doxapram. Naloxone was also given with morphine, since it was included in the original study ${ }^{1}$ and is widely recognised as the best available opiate antagonist.

\section{Methods}

Patients aged 16-60 years recovering from upper abdominal operations participated. They were visited before their operation, and consent was obtained for respiratory function tests and arterial blood sampling. The respiratory function tests, consisting of forced vital capacity (FVC), forced expiratory volume in one second $\left(F E V_{1}\right)$, and peak expiratory flow rate (PEFR), were carried out with a Monaghan electronic pulmonary function analyser, type $M 403 .^{3}$ Blood samples were taken at the same time from the radial artery into heparinised syringes and stored in an ice container for not more than 15 minutes before blood oxygen and carbon dioxide tensions were determined with a Cambridge EIL 48C analyser. All patients had a thorough physical examination. Those admitted to the study had a preoperative arterial oxygen tension $\left(\mathrm{PaO}_{2}\right)$ of over $10.6 \mathrm{kPa}(80 \mathrm{~mm} \mathrm{Hg})$ when breathing air and had no evidence of pulmonary or cardiovascular disease. 
Patients were sedated preoperatively with either diazepam or meprobamate by mouth; all were given atropine. Anaesthesia was induced with thiopentone or alphadolone-alphaxalone (Althesin) and maintained with $67^{\circ} \%$ nitrous oxide in oxygen with low concentrations of halothane or methoxyflurane and either pancuronium or tubocurarine as muscle relaxant with no narcotic analgesics. Patients who regained consciousness complaining of severe pain received a $10-\mathrm{ml}$ injection containing $20 \mathrm{mg}$ morphine sulphate either alone (the control group) or combined with $\$ .4 \mathrm{mg}$ naloxone or $140 \mathrm{mg}$ doxapram. Allocation of treatment was made on a randomised double-blind basis. The selected preparation was injected intravenously at $1 \mathrm{ml} / \mathrm{min}$ until the pain was relieved, the patient fell asleep, or the full $10 \mathrm{ml}$ had been injected.

In a further study an infusion of doxapram $2 \mathrm{mg} / \mathrm{min}$ was begun immediately the patients returned to the recovery ward and continued for two hours. Morphine was given as detailed above for severe pain. The condition of the patients was assessed one hour after the operation and on the first, third, and fifth postoperative days. Assessment consisted in testing respiratory function, estimating arterial blood gases, and making a detailed clinical examination of the chest, particularly noting cough, the expectoration of purulent sputum, and body temperature. On the first and fourth postoperative days chest radiography was performed.

In assessing and presenting the results (see table III) any abnormal finding is noted together with the overall incidence of definite pulmonary complications. These were taken as radiological evidence of miliary atelectasis, lobar collapse, or consolidation and physical signs indicative of a definite reduction in air entry to bases. $\mathrm{A} \mathrm{PaO}_{2}$ of under $10.6 \mathrm{kPa}$ (breathing air) was also taken as evidence of respiratory dysfunction, as was an $\mathrm{FEV}_{1}$ of less than $70^{\circ}{ }_{0}^{\circ}$.

\section{Results}

The four treatment groups (table I) were broadly comparable with respect to their physical characteristics, types of operation, etc. Table II shows the doses of morphine used. The average dose of naloxone was $0.35 \mathrm{mg}$, while the single dose of doxapram averaged $123.3 \mathrm{mg}$. Compared with the patients receiving morphine alone, those given naloxone required a significantly higher dose of opiate $(P<0.001)$ to achieve the desired effect, as did those given a single dose of doxapram $(P<0.005)$. In contrast, morphine requirements were not significantly altered in patients infused with doxapram.

Table III shows the frequency of complications occurring at any time during the first five days after operation. The overall incidence did not vary significantly in any group. There was, however, a reduction, although not statistically significant $(P=0.07)$, in the incidence of cough or expectoration of purulent sputum, or both, in patients given doxapram by infusion and in those given it by a single injection. When all patients given doxapram are considered together this reduction is highly significant $(P<0 \cdot 05)$. These two complications had mostly disappeared by the fifth day.

TABLE I-Details of patients in the four treatment groups

\begin{tabular}{|c|c|c|c|c|}
\hline & $\begin{array}{l}\text { Morphine } \\
\text { alone }\end{array}$ & $\underset{\text { Morphine }+}{\text { naloxone }}$ & $\begin{array}{c}\text { Morphine + } \\
\text { doxapram } \\
\text { (single dose) }\end{array}$ & $\begin{array}{c}\text { Morphine }+ \\
\text { doxapram } \\
\text { (infusion) }\end{array}$ \\
\hline 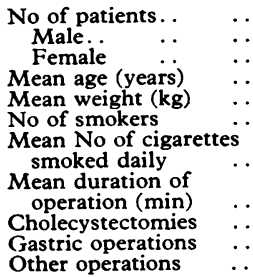 & $\begin{array}{rr}9 & 25 \\
16 & \\
& 45 \\
& 63 \\
& 18 \\
& 16 \\
& \\
& 70 \\
13 \\
10 \\
& 2\end{array}$ & $\begin{array}{rr}6 & 25 \\
19 & \\
& 40 \\
& 60 \\
& 16 \\
& 17 \\
& 66 \\
& 16 \\
& 6 \\
& 3\end{array}$ & $\begin{array}{rr} & 25 \\
18 & \\
& 42 \\
& 61 \\
& 13 \\
& 15 \\
& 60 \\
& 18 \\
& 6 \\
& 1\end{array}$ & $\begin{array}{rr}11 & 20 \\
9 & \\
& 47 \\
63 \\
10 \\
\\
\\
23 \\
\\
71 \\
\\
9 \\
\\
6 \\
5\end{array}$ \\
\hline
\end{tabular}

TABLE II-Average doses of morphine $( \pm S E)$ given for relief of immediate postoperative pain

\begin{tabular}{|c|c|c|}
\hline Treatment group & $\mathrm{mg}$ & $\mu \mathrm{g} / \mathrm{kg}$ \\
\hline $\begin{array}{l}\text { Morphine alone } \\
\text { Morphine + naloxone } \because \text { (single dose) } \\
\text { Morphine + doxapram } \\
\text { Morphine + doxapram (infusion) }\end{array}$ & $\begin{array}{l}15 \cdot 28 \pm 0.64 \\
17 \cdot 48 \pm 0.59 \\
17 \cdot 60 \pm 0.47 \\
13.90 \pm 0.59\end{array}$ & $\begin{array}{l}244 \pm 10 \cdot 4 \\
306 \pm 13 \cdot 9 \\
288 \pm 8 \cdot 6 \\
256 \pm 8 \cdot 5\end{array}$ \\
\hline
\end{tabular}

TABLE III-Percentage incidence of cough, expectoration of purulent sputum, abnormal physical signs, and adverse radiographic signs and percentage overall complication rate in patients in the four treatment groups

\begin{tabular}{|c|c|c|c|c|c|}
\hline Treatment group & Cough & Sputum & $\begin{array}{c}\text { Abnormal } \\
\text { physical } \\
\text { signs }\end{array}$ & $\begin{array}{l}\text { Radio- } \\
\text { logical } \\
\text { changes }\end{array}$ & $\begin{array}{c}\text { Any } \\
\text { compli- } \\
\text { cation }\end{array}$ \\
\hline \multirow{3}{*}{$\begin{array}{l}\text { Morphine } \\
\text { Morphine + naloxone } \\
\text { Morphine + doxapram } \\
\text { (single injection) } \\
\text { Morphine + doxapram } \\
\text { (infusion) }\end{array}$} & $\begin{array}{l}40 \\
48\end{array}$ & $\begin{array}{l}52 \\
56\end{array}$ & $\begin{array}{l}52 \\
52\end{array}$ & $\begin{array}{l}44 \\
28\end{array}$ & $\begin{array}{l}68 \\
72\end{array}$ \\
\hline & 20 & 28 & 40 & 32 & 64 \\
\hline & 25 & 25 & 25 & 45 & 65 \\
\hline
\end{tabular}

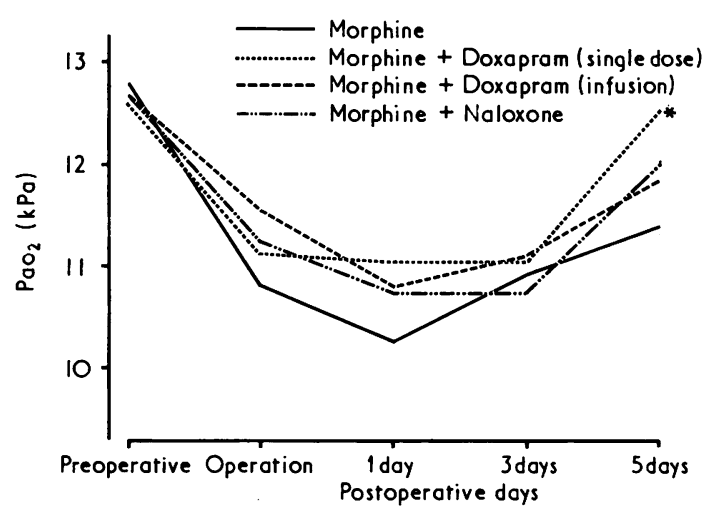

Mean $\mathrm{PaO}_{2}$ values before and after operation in patients on the four treatment regimens. $\star=$ Significant difference from the control series. For clarity SE at each point is omitted.

No significant differences in arterial carbon dioxide tension or pulmonary function were found in the four groups. The average oxygen tensions over the first five postoperative days are shown in the fig. Only in those patients given a single dose of doxapram with their morphine had the mean oxygen tension returned to the preopreative value on the fifth postoperative day.

\section{POOLED DATA}

The results of the present study and of the previous one, ${ }^{12}$ which was carried out in the same hospital using the same drugs and evaluation criteria, are compared in table IV. The pooled reduction in the incidence of cough or expectoration of sputum or both when a single dose of doxapram was given is highly significant (table V). The reduction was even greater after the infusion of doxapram. The use of naloxone also resulted in a reduction, but when the morphinenaloxone and morphine-doxapram series were compared the incidence of cough or expectoration of sputum or both was found to be significantly lower $(P<0.02)$ in the doxapram series.

TABLE IV-Incidence of cough or expectoration of sputum or both in present and previous series after upper abdominal operations

\begin{tabular}{|c|c|c|c|c|}
\hline Treatment group & $\begin{array}{c}\text { Previous } \\
\text { series }\end{array}$ & $\begin{array}{c}\text { Present } \\
\text { series }\end{array}$ & $\begin{array}{c}\text { Total } \\
\text { patients }\end{array}$ & $\underset{\%}{\text { Overall }}$ \\
\hline $\begin{array}{l}\text { Morphine alone } \\
\text { Morphine + doxapram } \\
\text { Single dose .. } \\
\text { Infusion } \\
\begin{array}{l}\text { Morphine + naloxone } \\
\text { Saline and other }\end{array}\end{array}$ & $\begin{array}{c}29 / 40 \\
14 / 60 \\
11 / 40 \\
3 / 20 \\
8 / 20 \\
14 / 20\end{array}$ & $\begin{array}{l}13 / 25 \\
12 / 45 \\
7 / 25 \\
5 / 20 \\
14 / 25\end{array}$ & $\begin{array}{lr} & 65 \\
& 105 \\
65 & \\
40 & \\
& 45 \\
& 20\end{array}$ & $\begin{array}{ll} & 64 \\
& 25 \\
28 & \\
20 & \\
& 49 \\
& 70\end{array}$ \\
\hline
\end{tabular}

TABLE $\mathrm{v}$-Significance of difference in incidence of postoperative cough or expectoration of sputum or both related to first analgesic given postoperatively. Figures in Parentheses are percentage incidences in the three treatment groups compared

Morphine alone (65) $v$ morphine + doxapram (single dose (28) Morphine alone (65) $v$ morphine + naloxone (49) $\begin{array}{lll}\mathbf{P} 0.00002 & \\ \mathbf{P} 0.07 & & \end{array}$ $\begin{array}{lll}\text { Morphine + doxapram (single dose) (28) } v \text { morphine + naloxone (49) } & \because & \text { P0.02 }\end{array}$

\section{Discussion}

The site of surgery and duration of operation and smoking habits, sex, weight, and age of the patient are known to be 
important factors in the incidence of postoperative pulmonary complications. By random selection we obtained groups that were broadly comparable with respect to these factors.

The two studies show conclusively that either a single dose or an infusion of doxapram given concurrently with morphine significantly reduces the incidence of persistent coughing or expectoration of purulent sputum or both during the first five days after operation. In contrast, these treatments fail to reduce the incidence of abnormal physical signs and radiological changes. This may indicate the presence of different aetiological mechanisms. Coughing and the expectoration of sputum suggest infection in the bronchial tree, whereas $x$-ray changes indicate marked alveolar collapse. It is difficult to envisage the means by which a short-acting drug such as doxapram reduces the former complications. The abolition of morphine-induced respiratory depression by doxapram cannot be the sole factor, since those patients given morphine and naloxone did not benefit to the same extent. More probably the brief period of hyperventilation induced by doxapram, even in the presence of morphine, ${ }^{1}$ is important. It is equally difficult to explain the significant difference in mean arterial oxygen tension on the fifth day after a single injection of doxapram (fig). Winnie et $a l^{4}$ suggested that a reduction in microatelectasis could result from hyperventilation, or that doxapram could increase pulmonary vascular perfusion. In our study there was no evidence of pronounced cardiovascular stimulation. In any event, it seems unlikely that a rise in cardiac output immediately after operation would be manifested by a raised $\mathrm{PaO}_{2}$ five days later.
The present findings are at variance with those of Gupta and Dundee $^{1}$ with respect to the influence of a single dose of doxapram on morphine dosage. In this study it resulted in a significant increase in the amount of morphine required, whereas this was not observed in the study of Gupta and Dundee. This is more likely to be due to an arousal effect of doxapram than to a true antagonism of morphine-induced analgesia. We have no reason to doubt previous findings, that doxapram did not reduce the analgesic efficacy of morphine and pethidine in experimentally induced pain.

The clinical importance of these findings must not be underestimated. Cough and the expectoration of purulent sputum are the most distressing of the postoperative pulmonary complications so far as the patient is concerned. There is good evidence to show that these are reduced by safe doses of doxapram.

THG is grateful for a research grant from the endowment funds of the Royal Victoria Hospital, Belfast, which enabled him to carry out this work. We are grateful to A H Robins Company Ltd for supplies of doxapram.

\section{References \\ ${ }^{1}$ Gupta, P K, and Dundee, J W, Anaesthesia, 1974, 29, 33. \\ 2 Gupta, P K, and Dundee, J W, Anaesthesia, 1974, 29, 40. \\ 3 Cox, P, Miller, L, and Petty, T L, Chest, 1973, 63, 517. \\ ${ }^{4}$ Winnie, A P, et al, Anesthesia and Analgesia, Current Researches, 1971, 50, 1043. \\ ${ }^{5}$ Dundee, J W, Gupta, P K, and Jones, C J, British Fournal of Pharma- cology, 1973, 48, 326P.}

\title{
Three-day and ten-day chemotherapy for urinary tract infections in general practice
}

\author{
C A C CHARLTON, A CROWTHER, J G DAVIES, J DYNES, M W A HAWARD, \\ P G MANN, S RYE
}

\section{Introduction}

Most women with frequency and dysuria are treated with antibiotics. It has been established ${ }^{12}$ that in the community about half of these women will have bacteriuria, for which a course of an appropriate antibiotic is indicated. Several studies ${ }^{34}$ carried out in general practice indicate that $80-90 \%$ of these infections are due to organisms sensitive to ampicillin or one of its analogues. There is, however, no authoritative indication of the length of time the antibiotics must be given to eradicate the infection. We describe here our attempt to answer this question. practice a three-day course of amoxycillin was as effective as a 10-day course of the same drug in the same dose. Relief of symptoms was equal in both groups and bacteriuria was eliminated equally successfully by both regimens. There was no significant difference between the two groups in the incidence of side effects from the drugs. The financial saving which could accrue from adopting this therapeutic regimen would be significant.

\section{Department of Urology, St Martin's Hospital, Bath}

C A C CHARLTON, MS, FRCS, consultant urological surgeon

Public Health Laboratory, Royal United Hospital, Bath P G MANN, MD, MRCPATH, director

St Chad's Surgery, Midsomer Norton, Avon

$M$ W A HAWARD, $M B, B C H I R$, general practitioner

J G DAVIES, MB, DOBSTRCOG, general practitioner

J RYE, MB, DOBSTRCOG, general practitioner

J DYNES, SRN, practice nursing sister

A CROWTHER, SRN, practice nursing sister

\section{Patients and methods}

All non-pregnant women who attended a general practice surgery complaining of frequency, dysuria, or loin pain entered the trial. The drug chosen for trial was amoxycillin (Amoxil). This is a semisynthetic penicillin with the same broad spectrum of activity as ampicillin, but with the advantages of better absorption from the gut and additional enhancement of bactericidal activity. Two drug regimens were used. Patients first seen during even-numbered months - that is, February, April, June, etc-were given nine capsules of Amoxil $500 \mathrm{mg}$ and instructed to take 1 capsule three times a day for three days. Patients who attended first during odd-numbered months-that is, January, March, May, etc-were given 30 capsules of amoxycillin $500 \mathrm{mg}$ and instructed to take 1 capsule three times a day for 10 days.

Two samples of urine for culture were taken from each patient before treatment began, one on the day of attendance at the surgery and the second the next morning, before the patient took the first capsule of amoxycillin. A standard inoculum of urine was collected with 